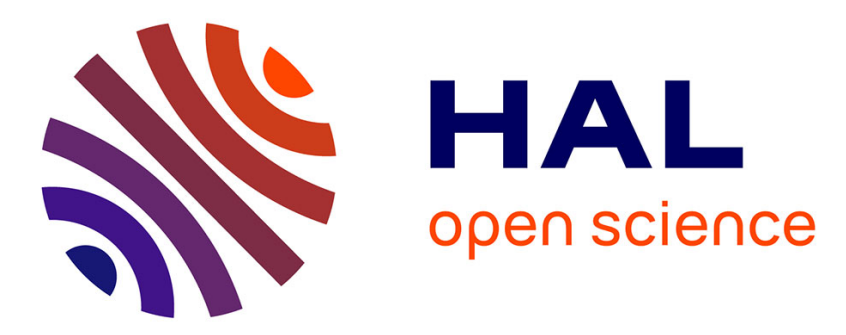

\title{
Listening to the sounds of war: an interview with Michel Chion
}

Luis Velasco-Pufleau, Michel Chion

\section{To cite this version:}

Luis Velasco-Pufleau, Michel Chion. Listening to the sounds of war: an interview with Michel Chion. Sound Studies: An Interdisciplinary Journal, 2017, 3 (2), pp.165-169. 10.1080/20551940.2017.1380371. hal-01757908

\section{HAL Id: hal-01757908 \\ https://hal.science/hal-01757908}

Submitted on 12 Oct 2018

HAL is a multi-disciplinary open access archive for the deposit and dissemination of scientific research documents, whether they are published or not. The documents may come from teaching and research institutions in France or abroad, or from public or private research centers.
L'archive ouverte pluridisciplinaire HAL, est destinée au dépôt et à la diffusion de documents scientifiques de niveau recherche, publiés ou non, émanant des établissements d'enseignement et de recherche français ou étrangers, des laboratoires publics ou privés. 


\title{
Listening to the sounds of war: an interview with Michel Chion
}

\author{
Luis Velasco-Pufleau \\ Department of Musicology and Dance Studies, Universität Salzburg, Salzburg, Austria
}

\begin{abstract}
Our aural memory is deeply connected to the physical and sensorial circumstances of listening. In the case of war, the act of listening is associated with specific places and emotions, but also to sound materiality and technological advancements in warfare. Do sounds of war leave particular traces on the people who heard or listened to them? How can audionarratives or sound descriptions from written sources shed light on the course and characteristics of armed conflicts? How can listening attitudes be strategic or inform us about sound sources on the battlefield? This interview with Michel Chion outlines the answers to these questions as it examines the role of language, fiction and listening in understanding the phenomenon of war.
\end{abstract}

\section{KEYWORDS}

Listening attitude; sounds of war; audionarrative; sonic violence; aural memory

\section{Introduction}

The work of the composer of musique concrète, director, teacher and historian of sound and audiovisual Michel Chion has been significant in the development of sound studies. Born in 1947 , he is a former collaborator of Pierre Schaeffer in the Groupe de recherches musicales (GRM) and the author of numerous books on sound, music and cinema, including AudioVision: Sound on Screen (New York: Columbia University Press, 1994), and Sound: An Acoulogical Treatise (Durham and London: Duke University Press, 2016). Michel Chion is currently preparing a Book of Sounds, a work in several languages on sound evocations in world literature from the earliest texts to the twenty-first century. In this interview held in Paris on 12 May 2017, Michel Chion reviewed some of the issues involved in this project and, in response to my questions, examines the role of language, fiction and listening in understanding the phenomenon of war.

Luis Velasco-Pufleau (LVP): My interest is in the descriptions and testimonies of the sounds of war by the people who experienced it, considering these testimonies as audionarratives of a particular event. Are these sounds evoked in the Book of Sounds that you are preparing? What were your main sources for writing it?

Michel Chion (MC): The book I am preparing is about the sounds in life, the sounds in history, through various literary sources, so inevitably war plays an important role here. 
However, I do not have any particular interest in the sounds of war, I speak of it today because it is the object of your own research, but it seems to me that this is a subject which interests just about everybody. Either because people have experienced war, or because they are the sons or daughters of people who have lived through war. Everyone has a connection to the sounds of war but, in my case, I never heard them directly. I was born in France in 1947, just after the end of World War II. My parents sometimes talked about the bombing of the British Royal Air Force during the occupation of France by the Germans because they lived in Creil in an area near a German air base. So there was a lot of bombing at this particular place, and on the Atlantic coast of France in general. However, they did not speak to me of the sounds in particular, but of the circumstances of these bombings, for example, if they were hidden in a cellar.

LVP: Because in our memory we cannot dissociate the sounds of an event from the circumstances in which we heard them?

MC: Certainly, one cannot separate the sounds from the circumstances and our own body in general. The sounds of war are mostly sounds of danger, they echo situations of fear. For example, bullets whistling above the head, a sound that is often mentioned in the written testimonies about World War I, refers to a particular context of violence. But this is ambivalent. A lot of people watch war movies and it gives them pleasure. Many of the ancient poems describe war to people who do not like war but it is a pleasure to evoke it and this does not entail fear.

However, certain sounds that are usually believed to be reserved for war, such as sounds of powerful weapons, may have been heard in other circumstances during peacetime. Let us take the sound of the cannon in its historical dimension. People think that the cannon was only used in warfare but this is not at all the case. It was sometimes used to sound the time, or to celebrate the birth of a prince. In certain towns in France where there were barracks, a cannon was fired in order to indicate that it was noon. Thus, the sound of the cannon was used as a signal, sometimes under happy circumstances. When Napoleon's son was born, cannons were fired. Similarly, since military orchestras also performed during celebrations, the drum rolling could also be associated with rejoicing, just as the firing of guns at the sky was an affirmation of energy.

LVP: How can these audionarratives or sound descriptions from written sources shed light on the course and characteristics of armed conflicts?

MC: In ancient texts there are many allusions to the sounds of metal, to the clash of swords, to the shields, to the weapons clanging. In these writings, there are topoi (commonplaces) in which one describes things that must always be mentioned. For example, in the lliad, the great epic poem attributed to Homer dedicated to an episode of the Trojan War, there are two allusions that often come up: the description of how weapons clashed when someone fell, because the weapons and armour made a metallic rattling sound, and the comparison of the noise of the combatants with the sound of the sea. But these phrases are poetic figures, details which make the description real. When you describe the arrow whistling through the air: it is not necessarily the people who were present but these poetic figures were found in other poems or myths. So even if they are written sources they must be read from a critical distance. The texts can be very beautiful but they do not translate the personal observation of the writer, rather the way it was told in the poetic tradition. 
After the invention of the firearm, the sounds of war began to be described differently, according to the development of these weapons: cannons, pistols, rifles, machine guns and aerial bombardments.

LVP: What can you tell us about the audionarratives of the wars of the twentieth century?

MC: The war for which we have many testimonies and precise writings - because many German, French, Italian, North American and other writers have recounted it - is World War I, the Great War. There were new weapons, the use of airplanes, new types of bullets, cannons, and there were a lot of sound details in many books written by people who had participated in the war, who were soldiers and were in the trenches. There is a well-known book by the French writer Henri Barbusse, Le Feu (published in 1916), it is his story as he lived it. Another French writer George Duhamel, who was a doctor, also experienced and heard the sounds of this war, similarly Roland Dorgeles, Louis-Ferdinand Celine, Apollinaire, and others. On the German side, there are the writings of Ernst Jünger, and the world-famous novel by the pacifist writer Erich Maria Remarque, Im Westen nichts Neues (All Quiet on the Western Front, published in 1929). At that time there were also Italian sources, for example a well-known text by the painter and poet Filippo Tommaso Marinetti on the new sounds of modern warfare, which this writer - who later became a fascist - found to be exalting and extraordinary.

LVP: How close are sound descriptions to true sounds and how much can they tell us about them?

MC: In my book I quote these sources, but I do not say that these are the true sounds, they are recounted sounds, it is different. In the case of sound description, one can never say that what the words tell us is close to the truth. However, the differentiation of words, the fact that there are words to designate things, even if these words are onomatopoeia, is already something. It is a way of humanising sound. But the sound of war, when one is in the place of action, is necessarily dramatised, because of the situation itself.

LVP: Do we inevitably appeal to metaphors to speak about sounds?

MC: Not necessarily. In each language there are words which serve to designate sounds for example in French: crépitement (crackling), crépitation (crepitus), craquement (cracking). Likewise, there are comparisons, I do not call them metaphors. There is what I call isophony, that is to say that the comparison by a writer or poet is often brought about by the real resemblance between sounds of different origin: a cause that does not correspond to a danger can make the same sound as a cause that corresponds to a danger. This is what I call the narrative blurring of sound. It sounds like something else: the sound of the rain sometimes resembles the sound of fire, the sound of the wind is sometimes not far from the sound of human moaning. It is the nature of the sound, which is an event that happens suddenly and is combined with other sound experiences. There are no more metaphors or comparisons when describing the sounds of war than there are when describing the sounds of nature. Sounds always make one think of other things, they are brought closer because different causes can produce similar sounds. Sometimes we are rather struck by the absence of sounds, which can be sometimes more frightening than the sound itself, at least the sounds we were expecting.

LVP: The sounds also inform us about the technological development of war weapons and their normalisation. 
MC: War has evolved a lot in history, to say the least: there are new weapons, new ways of fighting. Some sounds could be associated with war at some point, and then not. The sound of aircraft illustrates this phenomenon very well. When I was a child there were a lot of propeller aircrafts, airplanes that are used less today. For a time, jet aircraft were associated with war because only the army owned them. For example, when I was young there was a French Air Force base in Creil, the town north of Paris where I was born. At this time, when we heard a jet plane, we knew that it was always a warplane. A little later, when jet aircraft joint fleets of commercial airliners, the sound they produced gradually ceased to be associated with war.

For some time, in the late 1950s, when people heard the sound of a jet plane in a film, they often associated it with nuclear war, in particular with the atomic bomb. I remember that when I was a child the great fear was this kind of bomb. However, the sound produced by an atomic bomb is not an isolated sound such as in aerial bombardment. The noise it makes is not proportional to its power, witnesses of such an explosion recall a kind of earthquake but above all the blast of air and the heat it produces.

LVP: How can listening attitudes be strategic or inform us about sound sources on the frontline or the battlefield?

MC: An important issue in the context of war is to recognise the abnormal sounds within a sound environment, which could indicate danger. We use listening to inform ourselves but also to deceive. In some cases, listening allows us to determine who is shooting and from where they are shooting. It is also possible to use lures, false leads or things that make noise, to deceive the enemy about position or the number of fighters engaged.

LVP: How can one mobilise reduced listening in a context of war or armed violence?

MC: To me, the benefit of reduced listening is to structure the perception of sound, for the purpose of knowledge: realise that sounds have shapes and that they construct time. Reduced listening humanises the relationship with sound and helps to mobilise existing words of the language to name it. But it cannot be mobilised in combat situations, which are for the most part abrupt or unexpected events. It seems to me that it is more about the causal listening that can be mobilised. Given the ephemeral nature of sound, a real work of reduced listening can only be done on sounds that can be repeated identically, therefore recorded.

LVP: With regard to violent and traumatic events such as terrorist attacks, how can audionarratives tell us about the event itself? How can they help those who have experienced it to describe it?

MC: It seems to me that what is important is that the people who have survived it can recount their experience in one way or another: with graphic means, with language and with onomatopoeia. The important thing is the whole, not the sounds per se.

Sound is part of the violence experienced physically. For example, we have some testimonies from people who survived the Paris attacks of 13 November 2015 that they had hearing loss or tinnitus due to being too close to the detonations. Some guns make an immense and very rapid sound contrast between the silence that precedes the detonation and the sound produced by it; this can make people temporarily or permanently deaf.

LVP: For survivors, being able to talk about the experience is part of the process of making it thinkable or giving meaning to what has happened to them. 
MC: Yes, absolutely, but I will not say "thinkable", I will say "sayable" - something that can be said, even if it does not have "meaning". What is also very important is that these people can express the complexity and ambivalence of their feelings without being judged. People often talk about feeling guilty for having survived, but often they are afraid of others' judgment, especially today, where their words can be easily truncated or decontextualised by the media. Fiction makes it possible to express these ambivalent and complex feelings about this guilt. The fictional narrative humanises these feelings and makes them intelligible to other people.

LVP: If we talk about aural memory and the traces the sound leaves, do you think that the sounds of war leave particular traces on the people who heard or listened to them?

MC: There are sounds that coincide with traumatic events and acquire other meanings. There is a detail that often appears in the testimonies of World War l: the birds that continue to sing despite the sound of detonations. The battlefields were often in the countryside because the cities were fortified and defended. During the battles, there were many sounds of detonations but the birds continued to sing in the trees. Nature continues to live, creating a contrast, which I call an-empathic, between these sounds and those associated with human war.

The sounds are part of the traces of the event but the particularity of sound is that it leaves no visible traces. Even if you record a sound, it will represent something other than what happened at the same time. A recording is not the translation of a whole world of sound. The truth is that we cannot record the sound, just as it is not possible to film all the reality around us. However, because the sound exists in time, it can plunge the people who listen to it again back into the past.

I would like to emphasise that the question of sound in war is rather an abstract consideration, which very much depends on the singular experience of each individual. Personally, I have never been in a country at war and I am aware that the depiction of war in films is stylised while the documentary recordings convey only a weakened representation without danger. To conclude our interview, I would like to share with you an aural memory that my father, who was born in 1919, liked to recount from the time of occupied Paris during World War II. One winter, when the Germans requisitioned the petrol, there was very little traffic in the streets and the snow muffled the slightest sound. My father remembered in particular the extraordinary silence which filled the Place du Trocadero, just opposite the Eiffel Tower.

\section{Notes on contributor}

Luis Velasco-Pufleau is a musicologist and electroacoustic music composer. After completing his PhD in Music and Musicology at Paris-Sorbonne University in 2011, he was a postdoctoral researcher at the EHESS (2012-2013) and University of Salzburg (2013-2016), as well as a Balzan visiting fellow at the Faculty of Music of the University of Oxford (2015-2016). His research focuses on political, historical and aesthetics issues of twentieth and twenty-first century music, in particular related to music and conflict. $\mathrm{He}$ is co-editor of the electronic journal Transposition: Music and Social Sciences (https://transposition. revues.org), and editor of the research blog Music, Sound and Conflict (https://msc.hypotheses.org).

\section{ORCID}

Luis Velasco-Pufleau (D) http://orcid.org/0000-0002-1330-974X 